ПЛАХТІЙ О. А., канд. техн. наук, Український державний університет залізничного транспорту, НЕРУБАЦЬКИЙ В. П., канд. техн. наук, Український державний університет залізничного транспорту,

ШЕЛЕСТ Д. А., аспірант, Національний технічний університет «Харківський політехнічний інститут»,

ЦИБУЛЬНИК В. Р., аспірант, Український державний університет залізничного транспорту

\title{
Дослідження впливу скін-ефекту на втрати потужності в системах тягового електропостачання постійного струму
}

Наведено дослідження гармонічного складу тягових струмів у залізничній системі електропостачання постійного струму. В дослідженні враховано вплив вищих гармонік, зумовлених несиметрією живильної напруги, гармонік трифазних випрямлячів тягових підстаниій, роботу пасивного гібридного фільтра тягової підстаниї, а також вплив вищих гармонік, зумовлених імпульсним споживанням струмів тягових автономних інверторів напруги електрорухомого складу з асинхронним тяговим електроприводом. На прикладі фільтра тягової підстаниії ЕЧ-20 регіональної філї «Південна залізниця» АТ «Укрзалізниия» показано, щзо неканонічні гармоніки, зумовлені несиметрією живильної напруги, не придушуються існуючими режекторними ланками фільтра. Вплив вищих гармонік електрорухомого складу досліджено на прикладі роботи асинхронного тягового електропривода з вхідним LC-фільтром та автономним інвертором напруги електричного рухомого складу. Дослідження роботи автономного інвертора напруги електрорухомого складу виконано для режимів синусоїдальної широтно-імпульсної модуляції і просторово-векторної ииротно-імпульсної модулячії.

Показано, щзо застосування просторово-векторної широтно-імпульсної модуляції дає змогу покращити гармонічний склад тягових струмів і знизити їх коефіцієнт гармонічних спотворень. Визначення гармонічного складу та перехідни прочесів виконано шляхом компютерного моделювання в програмі Matlab/Simulink. Ha підставі визначеного гармонічного складу в контактній мережі наведено дослідження впливу скін-ефекту на розподіл щільності струму в перерізі контактного проводу системи залізничного електропостачання постійного струму. Дане дослідження було виконано також шляхом комп'ютерного моделювання в програмі Ansys Maxwell. Як результат, скін-ефект викликає збільшення еквівалентного активного опору провідника, щуо зумовлює збільшення додаткових втрат потужності в контактному проводі систем залізничного електропостачання, викликаних вищими гармоніками тягових підстанцій та вищими гармоніками електрорухомого складу.

Ключові слова: скін-ефект, гармонічний склад, система електропостачання постійного струму, втрати потужності, тягова підстанція постійного струму.

Вступ

Для систем тягового залізничного електропостачання постійного струму характерним $є$ досить широкий гармонічний склад $[1,2]$. Причиною виникнення вищих гармонік є:

- спотворення та несиметрія напруги в живильній трифазній загально-промисловій мережі;

- вищі гармоніки, викликані роботою шестипульсних та дванадцятипульсних випрямлячів тягових підстанцій;

- вищі гармоніки, викликані діодними та імпульсними напівпровідниковими перетворювачами електрорухомого складу.
Вищі гармоніки викликають негативний вплив на електромагнітну сумісність 3 рейковими колами залізничного електропостачання (вони можуть викликати збої в системі залізничної автоматики) [3-5]. Крім цього, вищі гармоніки обумовлюють збільшення втрат потужності в системі залізничного електропостачання внаслідок збільшення еквівалентного опору мережі під дією скін-ефекту [6-8]. Робота продовжує дослідження, виконані авторами в попередні роки $[9,10]$, і базується на результатах та науковому доробку, частково опублікованих у роботах $[11,12]$.

(ㄱ О. А. Плахтій, В. П. Нерубацький, Д. А. Шелест, В. Р. Цибульник, 2021 


\section{Мета роботи}

Метою роботи $є$ аналіз впливу вищих гармонік на системи залізничного тягового електропостачання постійного струму. Для досягнення мети було поставлено такі завдання:

- визначення гармонічного складу в контактній мережі постійного струму, зумовленого дією випрямляча тягової підстанції, фільтра тягової підстанції та автономного інвертора напруги електрорухомого складу;

- дослідження впливу скін-ефекту на розподіл щільності струму в контактному проводі для гармонік струму, характерних для контактної мережі постійного струму, шляхом імітаційного комп'ютерного моделювання в програмі Ansys Maxwel.

\section{Виклад основного матеріалу}

У більшості тягових підстанцій постійного струму застосовують шестипульсні випрямлячі з послідовним з'єднанням пасивних фільтрів низьких частот 3 режекторними ланками (рис. 1). Для схеми шестипульсного випрямляча характерні вищі гармоніки струму, кратні частоті пульсації вихідної напруги, тобто 300 Гц, 600 Гц, 900 Гц тощо [13, 14]. Для придушення гармонічного складу вихідної напруги тягових підстанцій використовують пасивні фільтри низьких частот 3 додаванням режекторних ланок (рис. 2) [15, 16]. Для подальшого аналізу було взято параметри фільтра тягової підстанції ЕЧ-20 регіональної філії «Південна залізниця» АТ «Укрзалізниця», що наведено в табл. 1.

Окрім впливу вищих гармонік тягових підстанцій, на контактну мережу діють вищі гармоніки спожитого електрорухомим складом струму [17].

Таблиця 1

Параметри фільтра тягової підстанції ЕЧ-20 «Балаклея» регіональної філії «Південна залізниця» АТ «Укрзалізниця»

\begin{tabular}{|c|c|}
\hline Параметр & Значення \\
\hline$C 1$, мкф & 89,2 \\
\hline$C 2$, мкф & 36,28 \\
\hline$C 3$, мкф & 23,96 \\
\hline$C 4$, мкф & 13,83 \\
\hline$C 5$, мкф & 28,8 \\
\hline$L 1, \mathrm{м} \Gamma \mathrm{H}$ & 0,9 \\
\hline$L 2, \mathrm{м} \Gamma \mathrm{H}$ & 2,98 \\
\hline$L 3, \mathrm{м} \Gamma \mathrm{H}$ & 1,97 \\
\hline$L 4, \mathrm{м} \Gamma \mathrm{H}$ & 1,32 \\
\hline$L 5, \mathrm{м \Gamma \textrm {H }}$ & 1,26 \\
\hline
\end{tabular}

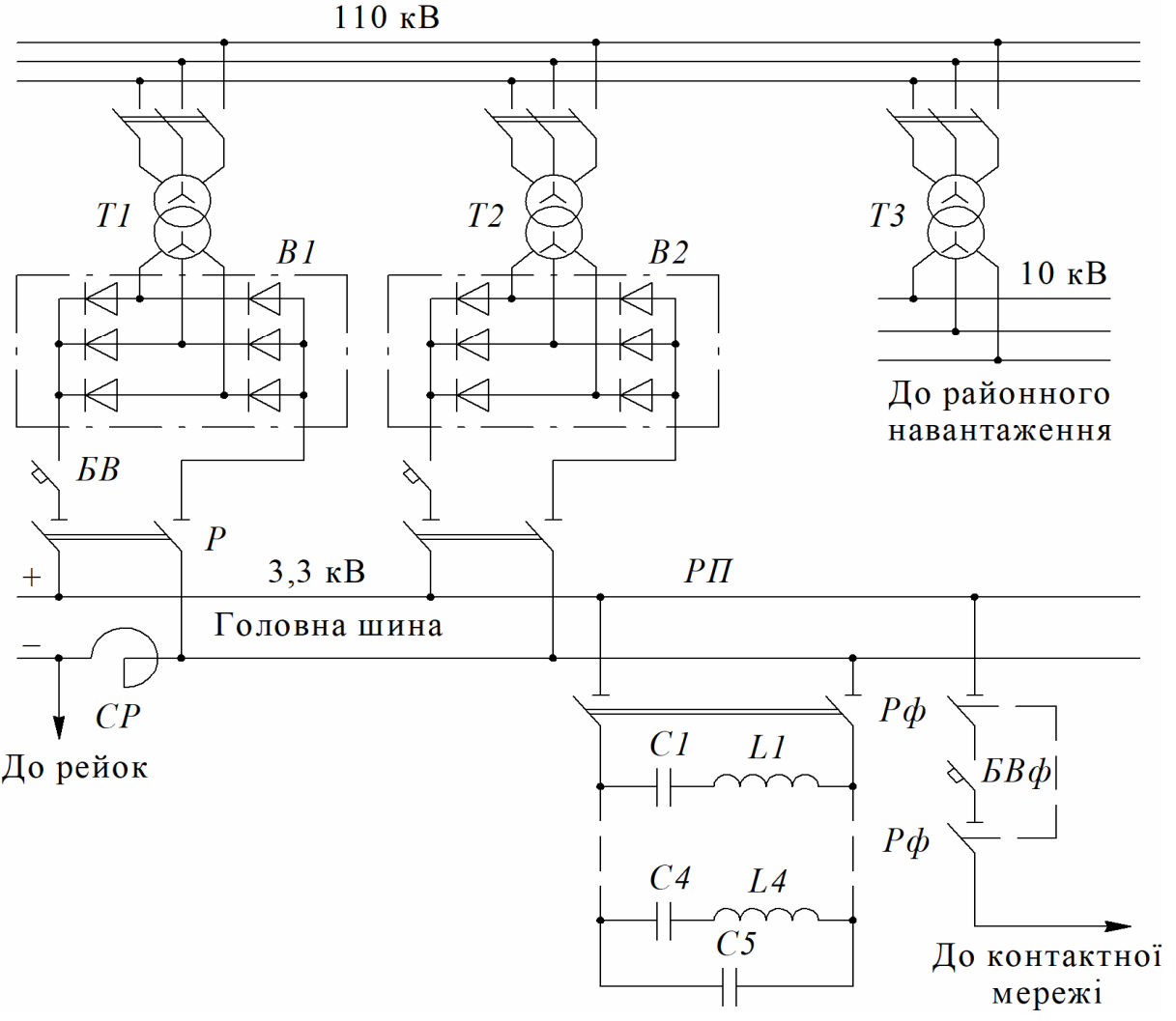

Рис. 1. Схема шестипульсного випрямляча тягової підстанції 
LI

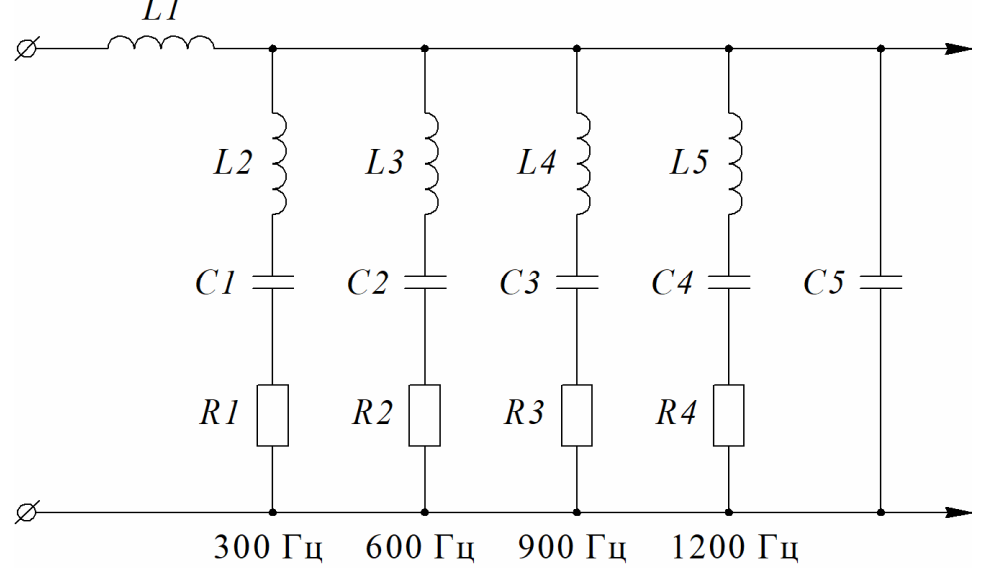

Рис. 2. Схема типового фільтра шестипульсного випрямляча тягової підстанції

Тяговий рухомий склад з реостатно-контакторною системою керування практично не зумовлює емісії вищих гармонік спожитих струмів до системи електропостачання [18, 19]. Проте більш сучасний електричний рухомий склад має у своєму складі широтно-імпульсні перетворювачі (при роботі 3 двигунами постійного струму) [20] або трифазні автономні інвертори напруги (при роботі 3 асинхронними тяговими електродвигунами) (рис. 3) [21].

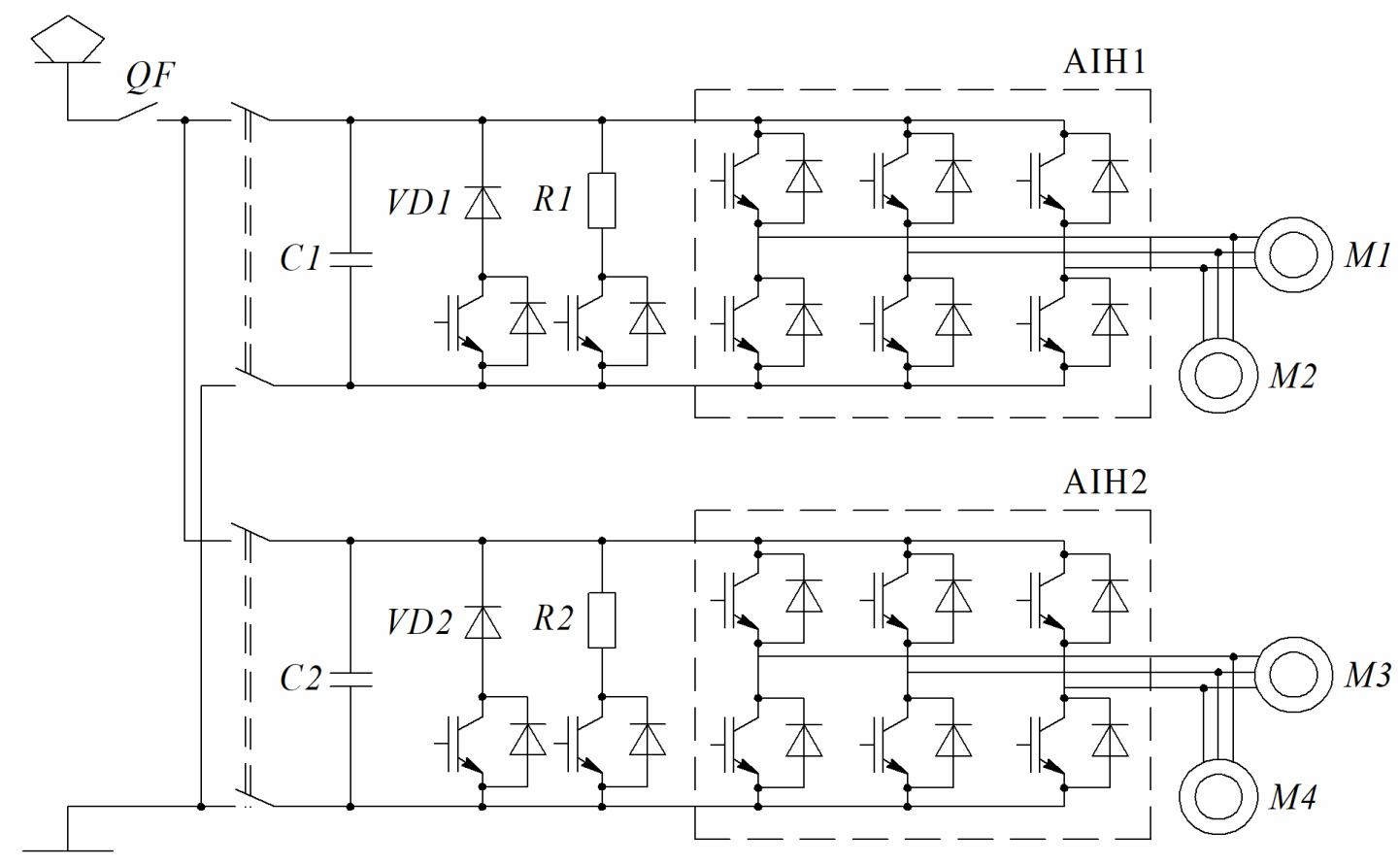

Рис. 3. Типова схема тягового асинхронного електропривода електричного рухомого складу постійного струму

Для визначення гармонічного складу контактної мережі постійного струму для системи залізничного електропостачання 3 асинхронним електроприводом в якості навантаження в системі Matlab/Simulink було виконано комп'ютерне моделювання (рис. 4).

Подана модель має такі складові: випрямляч тягової підстанції, фільтр тягової підстанції, RLпараметри мережі, вхідний фільтр електрорухомого складу, автономний інвертор напруги, еквівалентний LC-опір асинхронного двигуна.

За допомогою імітаційної моделі було визначено амплітудно-частотну характеристику (АЧХ) фільтра тягової підстанції, яку наведено на рис. 5. 


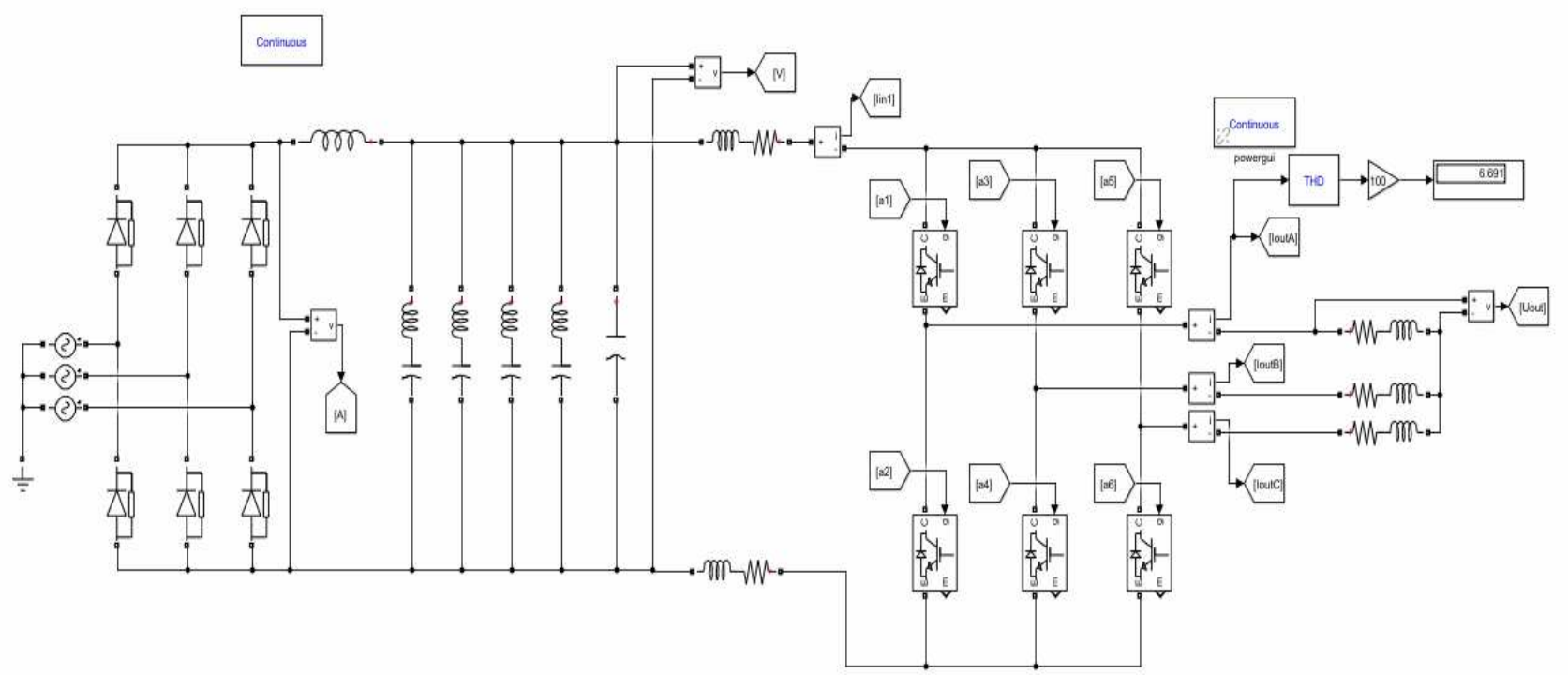

Рис. 4. Matlab-модель системи електропостачання постійного струму з асинхронним електроприводом в якості навантаження

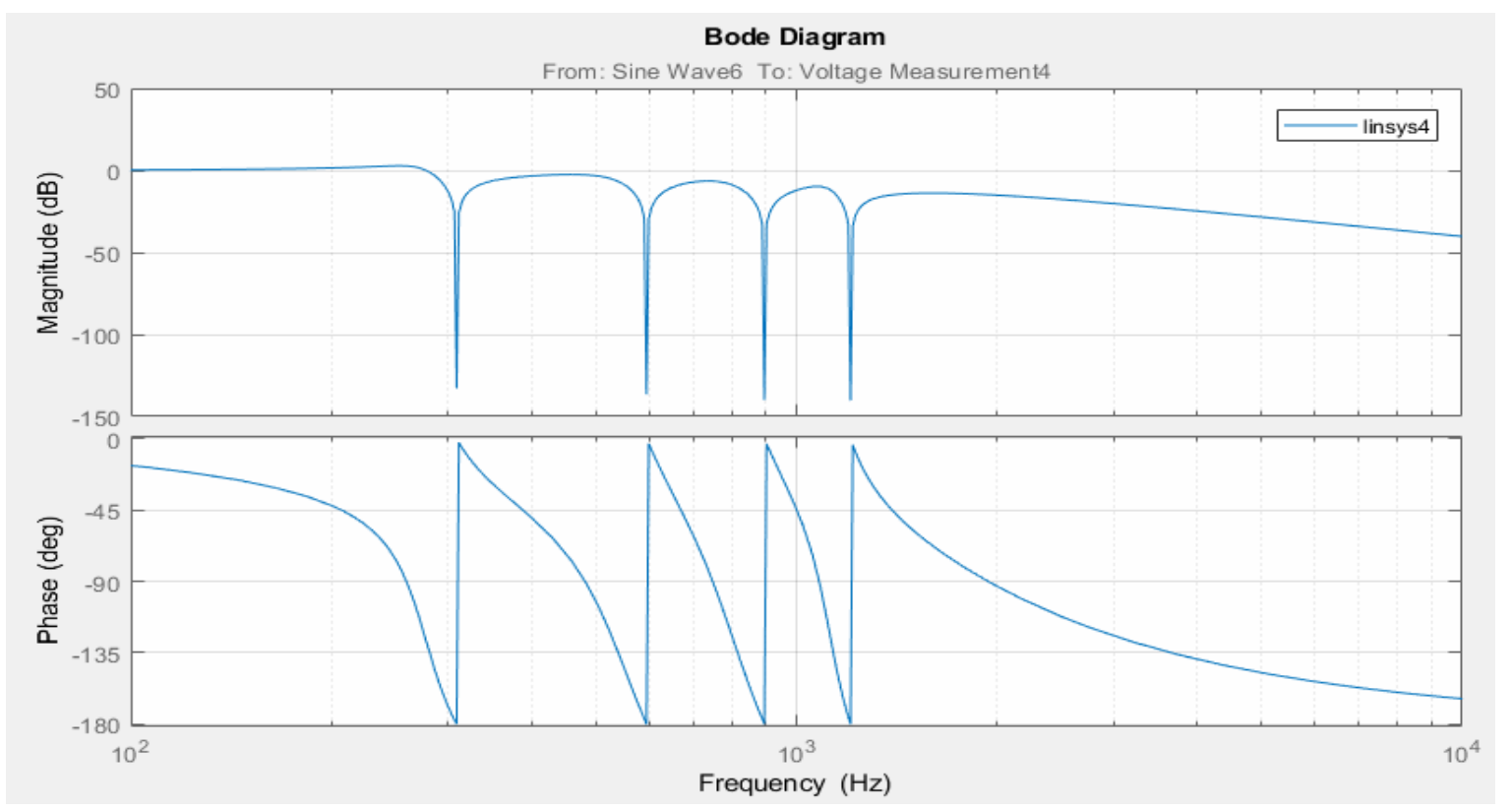

Рис. 5. АЧХ фільтра тягової підстанції

3 поданої АЧХ видно, що режекторні ланки налаштовані на частоти 300 Гц, 600 Гц, 900 Гц, 1200 Гц. Проте даний фільтр практично не придушує неканонічні гармоніки, пов'язані 3 несиметрією живильної трифазної напруги. При цьому нормально допустиме і гранично допустиме значення коефіцієнта несиметрії напруг за зворотною послідовністю в точках загального приєднання до електричних мереж склало 2 і 4 \% відповідно.

Результати гармонічного аналізу вихідної напруги шестипульсного випрямляча тягової підстанції та вихідної напруги фільтра тягової підстанції наведено на рис. 6 і рис. 7 відповідно. 

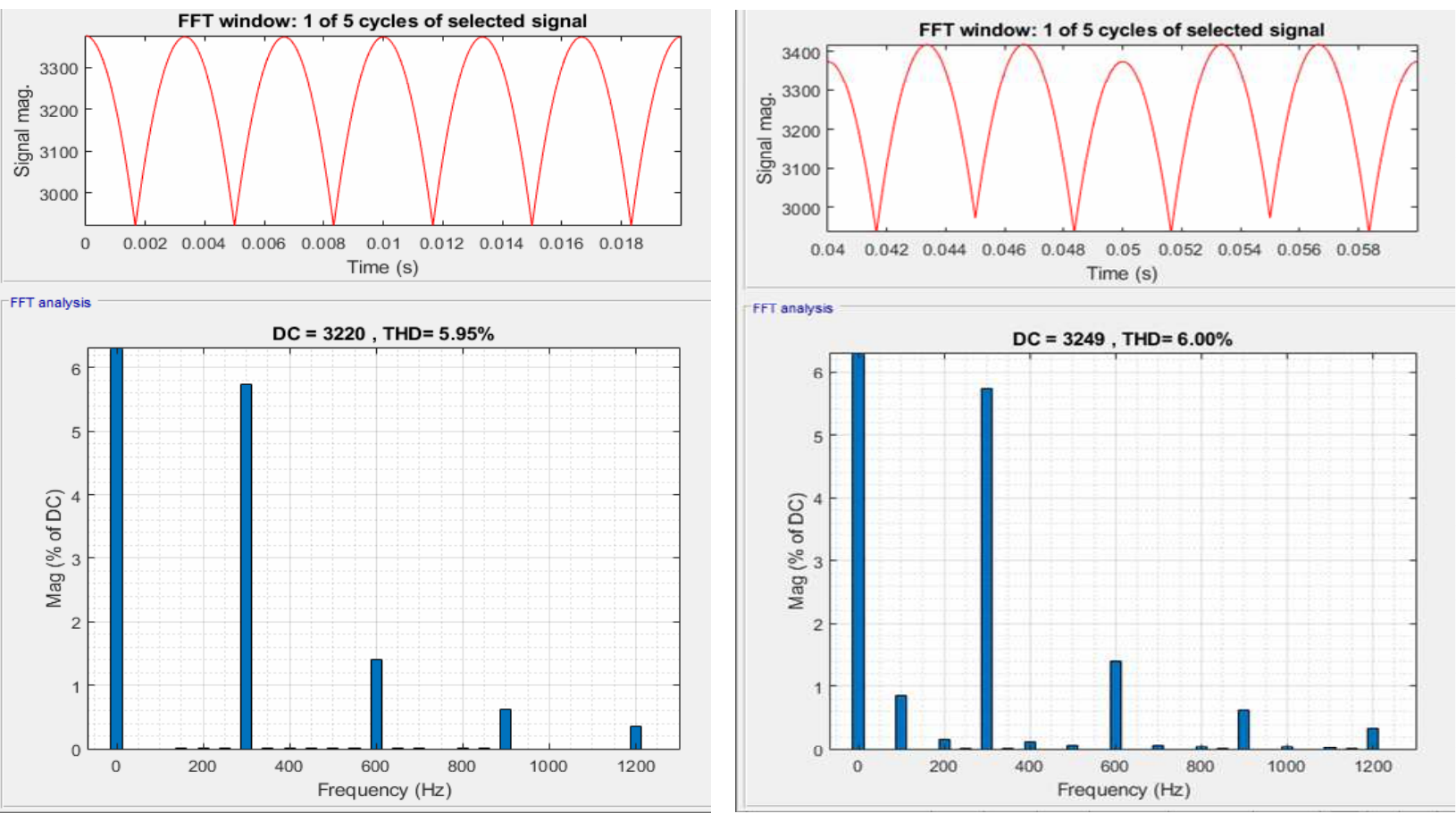

a)

б)

Рис. 6. Гармонічний склад вихідної напруги трифазного випрямляча (вхідна напруга фільтра): $a$ - без наявності несиметрії живильної трифазної напруги; $\sigma$ - за наявності несиметрії живильної трифазної напруги
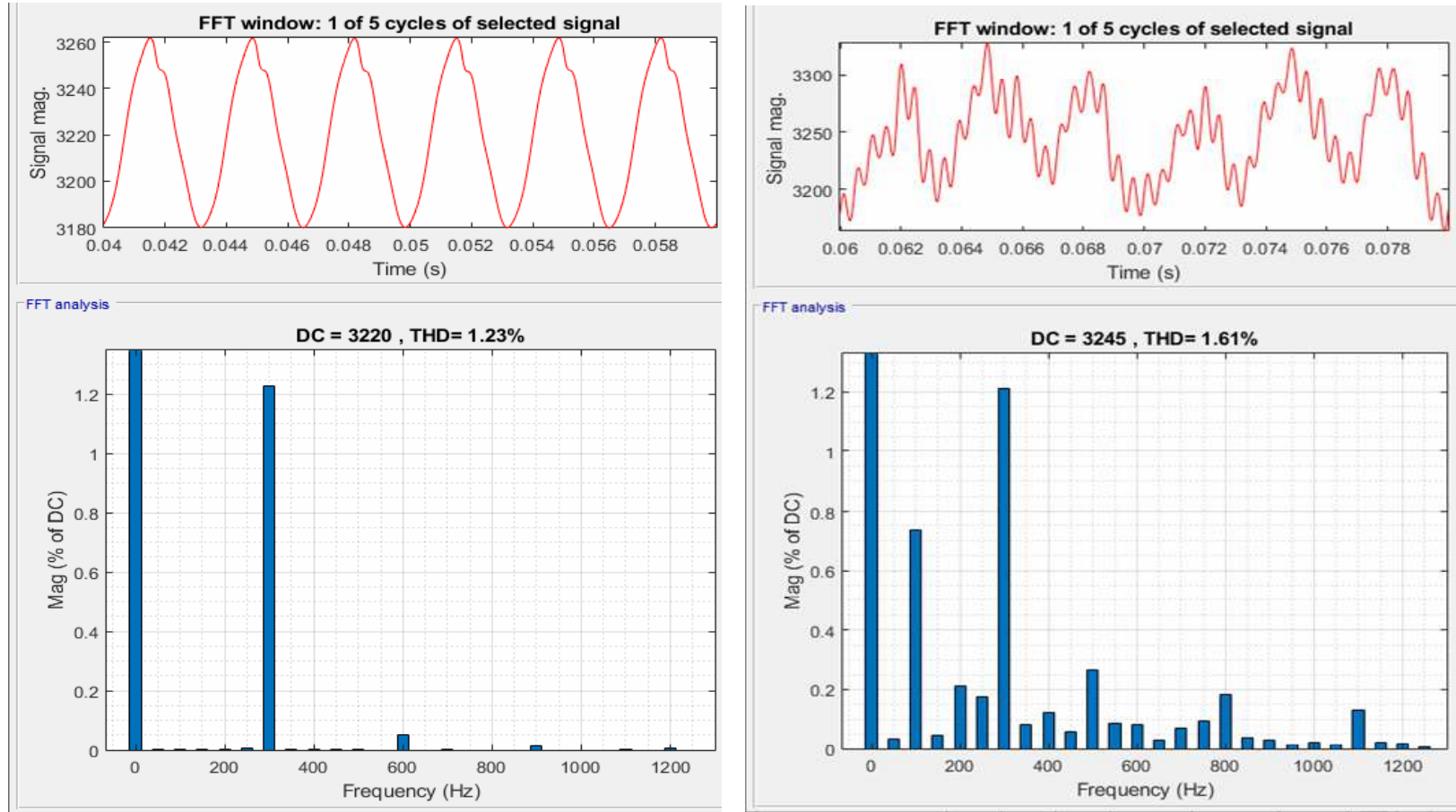

a)

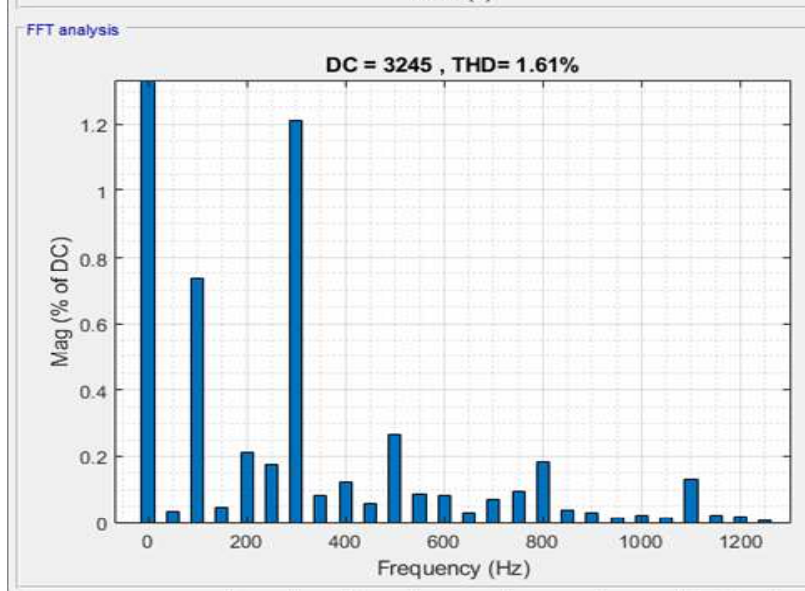

б)

Рис. 7. Гармонічний склад вихідної напруги фільтра тягової підстанції: $a$ - без наявності несиметрії живильної трифазної напруги; б - за наявності несиметрії живильної трифазної напруги 
Як показано в моделюванні, застосування пасивного фільтра, поданого на рис. 2, дає змогу значною мірою знизити пульсації вихідної напруги шестипульсного випрямляча 3450 В до 80 В. Крім того, суттєво знижуються значення канонічних гармонік 300 Гц, 600 Гц, 900 Гц. При цьому 3 проведеного Фур'є-аналізу випливає, що за наявності несиметрії в гармонічному спектрі вихідної напруги випрямляча додаються гармоніки з частотами 100 Гц і 200 Гц, які є неканонічними. В цьому випадку фільтр випрямляча тягової підстанції ці гармоніки (100 Гц і 200 Гц) практично не придушує, i вони без придушення проходять до контактної мережі.

Крім впливу на гармонічний склад вихідної напруги, фільтр тягової підстанції впливає на протікання перехідних процесів при ступінчастій зміні струму навантаження [22-24].

На рис. 8 наведено реакцію передавальної функції фільтра на ступінчасту зміну вхідної напруги.

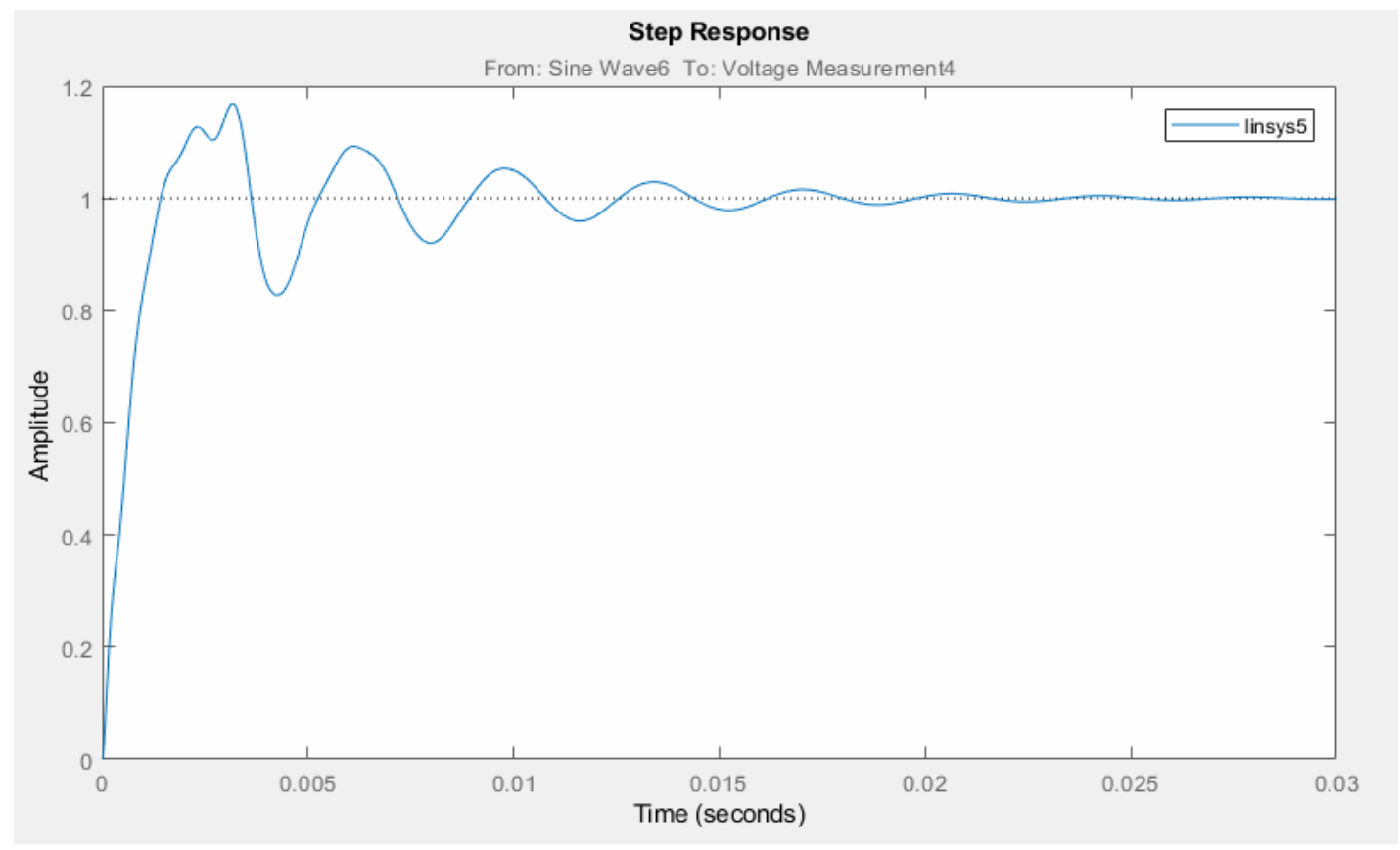

Рис. 8. Реакція фільтра тягової підстанції на одиничний ступінчастий вплив

Як видно 3 рис. 8, наведений фільтр тягової підстанції при ступінчастій зміні вхідної напруги зумовлює перенапругу $18 \%$ від установленого значення.

Гармонічний спектр вищих гармонік вхідного струму автономного інвертора напруги електрорухомого складу при застосуванні в ньому синусоїдальної та просторово-векторної ШІМ наведено на рис. 9.

Відповідно до рис. 9, у спектрі вищих гармонік вхідного струму найбільше значення мають гармоніки, пов' язані з частотою широтно-імпульсної модуляції.

Відомі дослідження, що описують вплив скінефекту на розподіл щільності струму, збільшення еквівалентного опору i, як наслідок, збільшення втрат потужності, справедливі виключно для циліндричних провідників і для проводів, що мають нестандартну геометрію, не підходять $[25,26]$.

Надані в літературі аналітичні вирази описують розподіл щільності струму по циліндричному провіднику [27, 28]. Недоліком існуючих виразів $є$ те, що вони справедливі тільки для циліндричних провідників, а для провідників нециліндричної форми дають помилкові значення. 


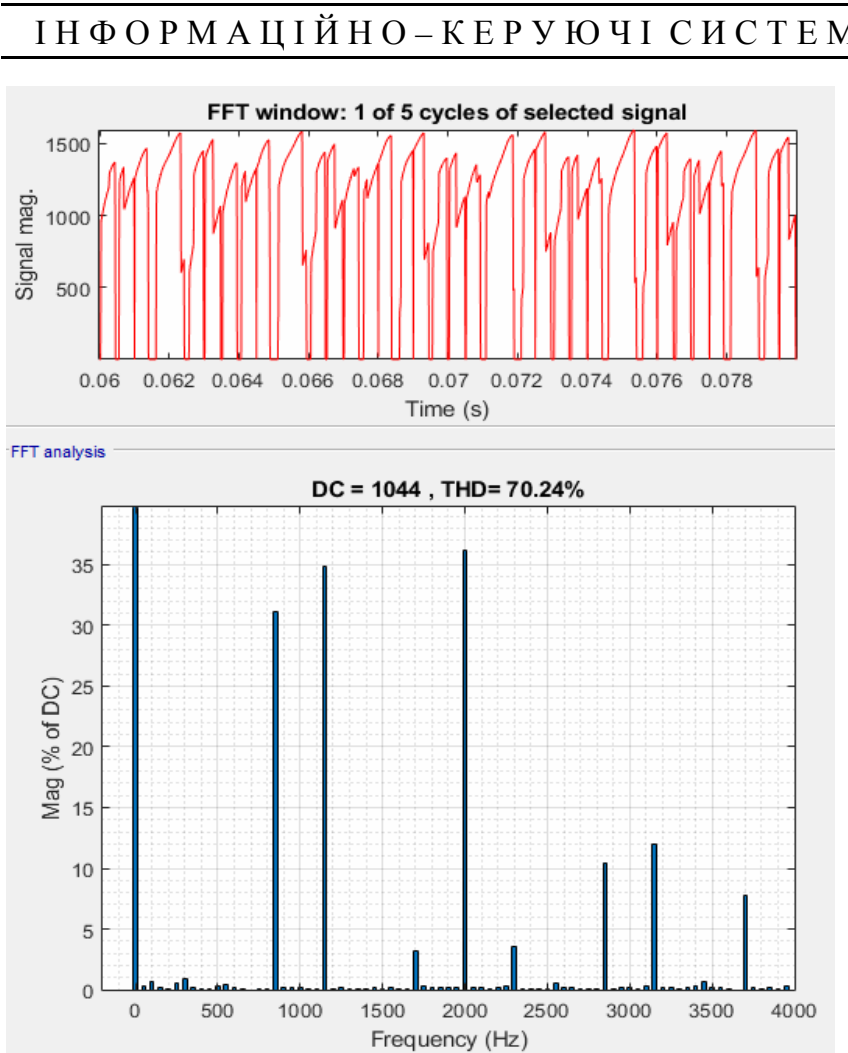

Рис. 9. Гармонічний склад вхідного струму інвертора при синусоїдальній ШІМ

У системах залізничного електропостачання широко використовується контактний провід типу МФ [29], що має конфігурації МФ-65, МФ-85, МФ-100, МФ-120, МФ-150. Габарити та геометричні параметри контактного проводу типу МФ-100 наведено на рис. 10 і табл. 2.

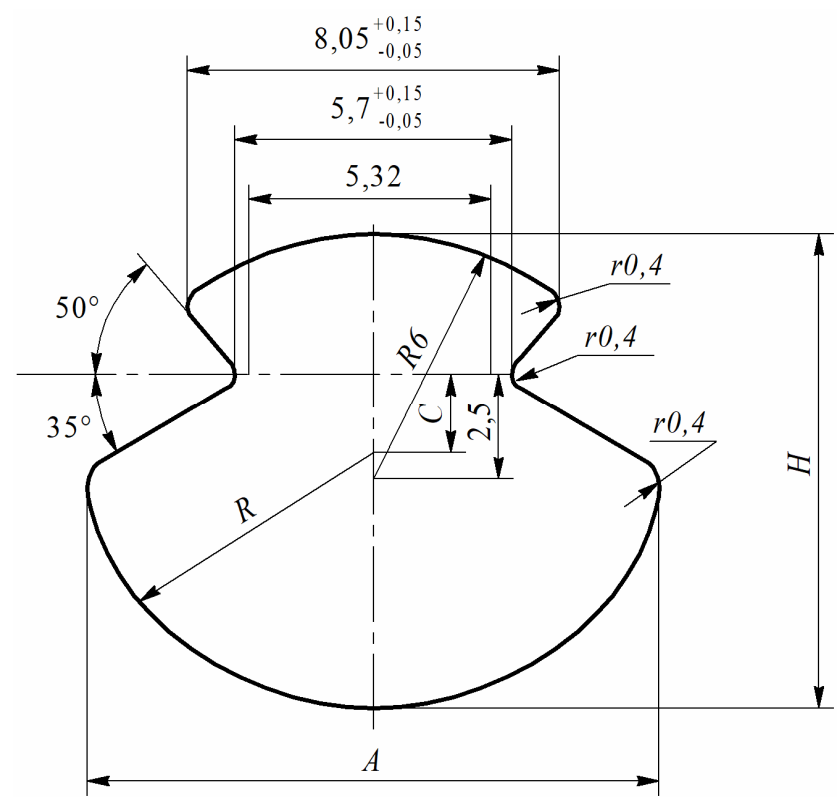

Рис. 10. Переріз контактного проводу МФ-100 [30]
Технічні характеристики проводу МФ-100 наведено в табл. 3.

Таблиця 2

Геометричні параметри контактного проводу [30]

\begin{tabular}{|l|l|l|l|l|}
\hline \multirow{2}{*}{$\begin{array}{c}\text { Номінальний переріз, } \\
\text { мм }^{2}\end{array}$} & \multicolumn{4}{|c|}{ Розміри, мм } \\
\cline { 2 - 5 } & \multicolumn{1}{|c|}{$A$} & $H$ & $C$ & $R$ \\
\hline 65 & $10,19 \pm 0,2$ & $9,3 \pm 0,08$ & 0,5 & 5,3 \\
\hline 85 & $11,76 \pm 0,22$ & $10,8 \pm 0,1$ & 1,3 & 6,0 \\
\hline 100 & $12,81 \pm 0,25$ & $11,8 \pm 0,11$ & 1,8 & 6,5 \\
\hline 120 & $13,9 \pm 0,3$ & $12,9 \pm 0,12$ & 2,4 & 7,0 \\
\hline 150 & $15,5 \pm 0,32$ & $14,5 \pm 0,13$ & 3,2 & 7,8 \\
\hline
\end{tabular}

Таблиця 3

Технічні характеристики проводу МФ-100 [30]

\begin{tabular}{|c|c|}
\hline Параметр & Значення \\
\hline Робоча температура експлуатації, ${ }^{\circ} \mathrm{C}$ & $\begin{array}{ll}\text { від }-60 \text { до } \\
+40\end{array}$ \\
\hline $\begin{array}{l}\text { Тривала допустима } \\
\text { нагріву жил, не більше, }{ }^{\circ} \mathrm{C}\end{array}$ & +90 \\
\hline Термін служби, не менше, роки & 6 \\
\hline $\begin{array}{ll}\text { Температурний } & \text { коефіцієнт } \\
\text { електроопору на } 1{ }^{\circ} \mathrm{C} & \end{array}$ & 0,00403 \\
\hline $\begin{array}{l}\text { Тимчасовий опір розриву, МПа } \\
\left(\mathrm{H} / \mathrm{Mм}^{2}\right)\end{array}$ & $160 \ldots 195$ \\
\hline Відносне подовження, не менше, \% & 3,5 \\
\hline $\begin{array}{l}\text { Число перегинів до повного } \\
\text { руйнування, не менше }\end{array}$ & 3 \\
\hline $\begin{array}{l}\text { Число скручувань до руйнування, не } \\
\text { менше }\end{array}$ & 4 \\
\hline $\begin{array}{l}\text { Розрахункова маса } 1 \text { км контактного } \\
\text { проводу, кг }\end{array}$ & 755 \\
\hline
\end{tabular}

У програмному пакеті Ansys Maxwell [31, 32] було розроблено модель контактного проводу типу МФ-65, МФ-85, МФ-100, МФ-120, МФ-150. На рис. 11 наведено розподіл щільності струму з частотою 50 Гц.

Як видно 3 рис. 11, електричний струм з частотою 50 Гц практично не викликає істотного ефекту витіснення струму 3 центру проводу. Більш точно, в центрі контактного проводу щільність струму 3 частотою 50 Гц буде на 1,5\% нижче, ніж на поверхні.

На рис. 12 наведено розподіл щільності струму 3 частотою 300 Гц. 


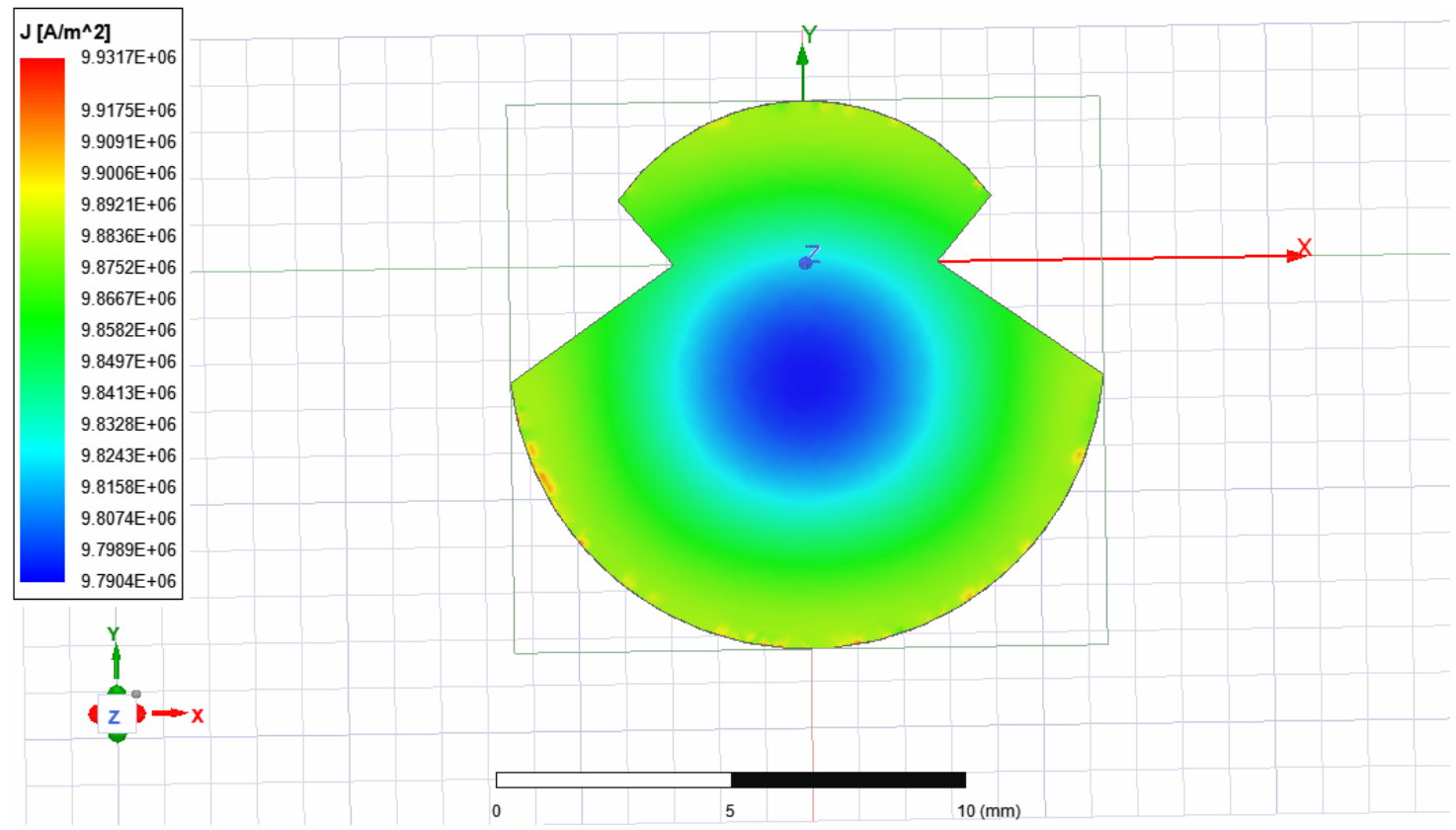

Рис. 11. Розподіл щільності струму з частотою 50 Гц

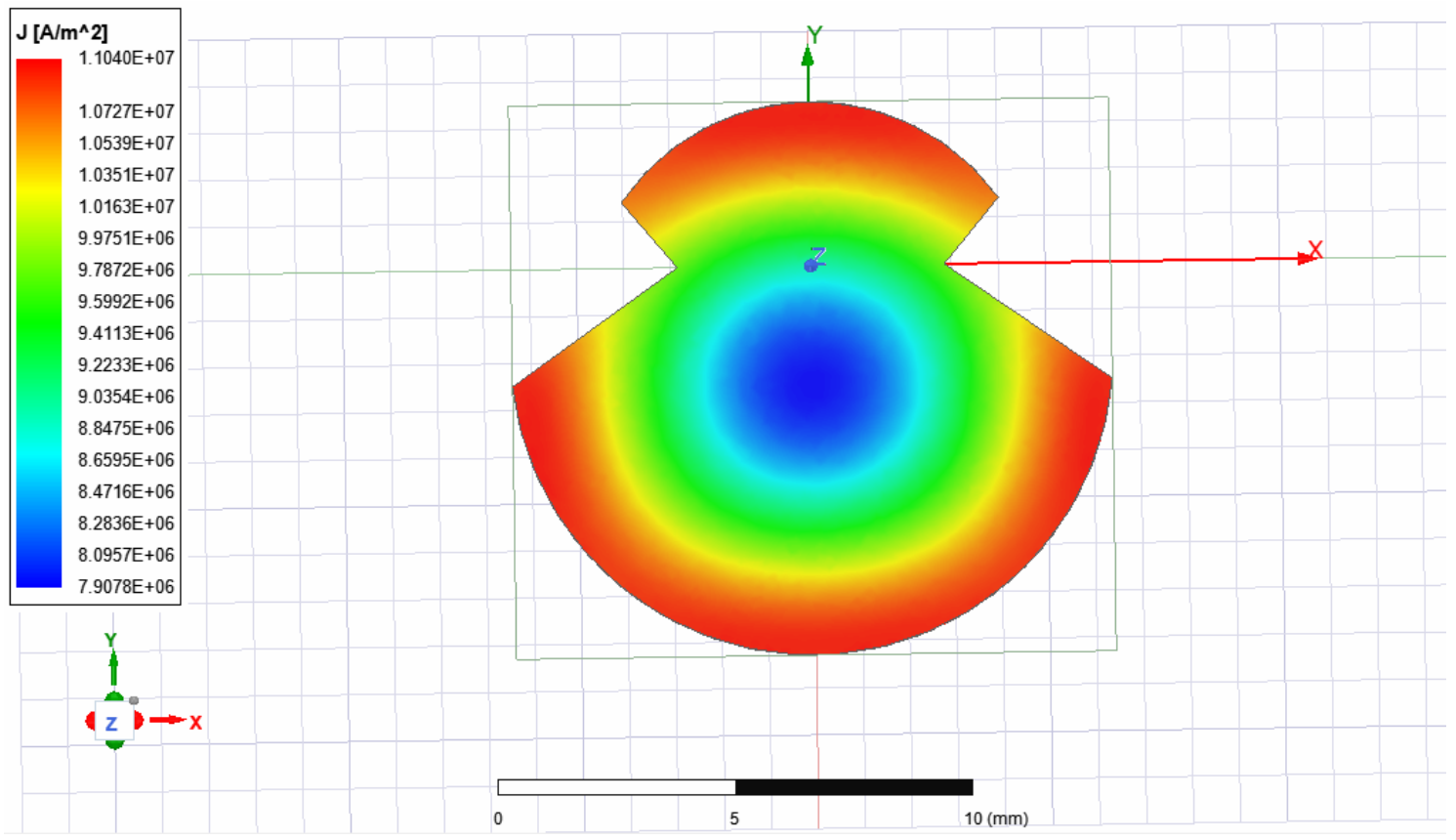

Рис. 12. Розподіл щільності струму з частотою 300 Гц

Як видно з рис. 12, електричний струм з частотою 300 Гц викликає більш істотний ефект витіснення струму 3 центру проводу. Більш точно, в центрі контактного проводу щільність струму 3 частотою 300 Гц буде на 40 \% нижче, ніж на поверхні.
На рис. 13 наведено розподіл щільності струму 3 частотою 1000 Гц. 


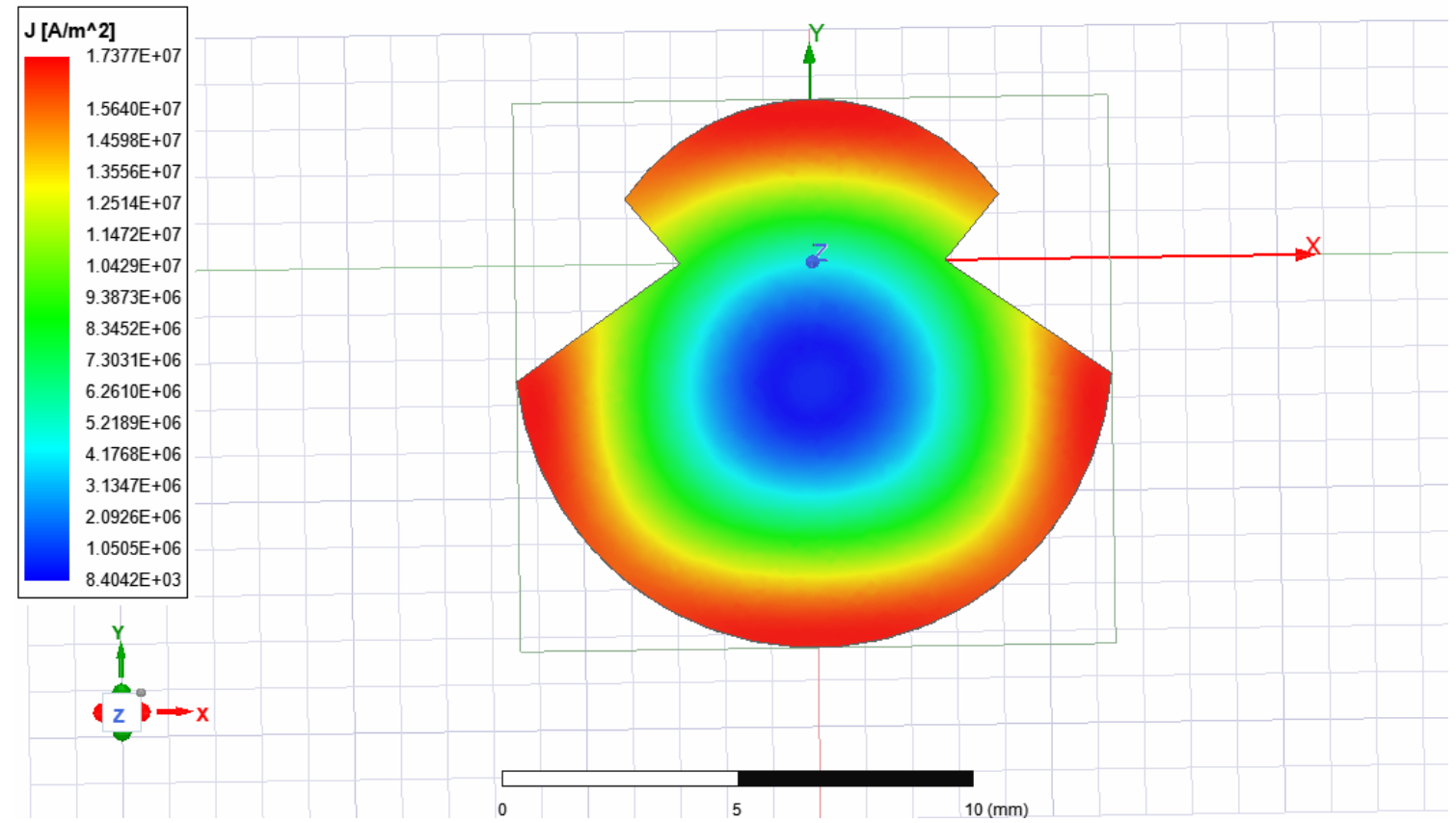

Рис. 13. Розподіл щільності струму з частотою 1000 Гц

Як видно 3 рис. 13, електричний струм 3 частотою 1000 Гц викликає більш істотний ефект витіснення струму 3 центру проводу. Більш точно, в центрі контактного проводу щільність струму з частотою 100 Гц буде меншою у два рази, ніж на поверхні.

\section{Висновки і рекомендації щодо подальшого використання}

У програмному середовищі Matlab/Simulink було виконано розробку моделі системи тягового електропостачання постійного струму, навантаженням якої $\epsilon$ трифазний автономний інвертор напруги електрорухомого складу. На прикладі фільтра тягової підстанції ЕЧ-20 регіональної філії «Південна залізниця» АТ «Укрзалізниця» показано, що неканонічні гармоніки, зумовлені несиметрією вхідної трифазної напруги, практично не придушуються фільтром тягової підстанції.

У програмному пакеті Ansys Maxwell було проведено моделювання розподілу щільності струму в контактному проводі типу МФ-100 при протіканні струмів з частотою 50 Гц, 300 Гц і 1000 Гц. Проведене моделювання показало, що для вищих гармонік струму 3 частотами 300 Гц і 1000 Гц еквівалентний переріз проводу змінюється на $15 \%$ і $40 \%$ відповідно. Таким чином, при обліку втрат потужності в активному опорі контактної мережі від вищих гармонік струму необхідно враховувати зміну еквівалентного опору, викликану дією скін-ефекту.

Статтю підготовлено в рамках проведення дослідження за держбюджетною темою «Розробка наукових основ підвищення енергетичної ефективності та покращення якості електроенергї в електричних мережах» (ДРН 0121U109440) за фінансової підтримки Міністерства освіти $i$ науки України.

\section{Список використаних джерел}

1. Plakhtii O., Nerubatskyi V., Ryshchenko I., Zinchenko O., Tykhonravov S., Hordiienko D. Determining additional power losses in the electricity supply systems due to current's higher harmonics. Eastern-European Journal of Enterprise Technologies. 2019. Vol. 1, No. 8 (97). P. 6-13. DOI: $10.15587 / 1729-4061.2019 .155672$.

2. Nerubatskyi V., Plakhtii O., Kotlyarov V. Analysis of topologies of active four-quadrant rectifiers for implementing the INDUSTRY 4.0 principles in traffic power supply systems. International scientific journal «Industry 4.0». 2019. Vol. 4, Issue 3. P. 106-109.

3. Щека В.ІІ. Організація захисту рейкових кіл від електромагнітних завад з боку контактної мережі. Електромагнітна сумісність та безпека на залізничному транспорті. 2011. № 1. С. 84-90.

4. Нерубацький В. П., Плахтій О. А., Гладка А. В. Покращення електромагнітної сумісності тягового електропривода змінного струму шляхом застосування 4QS-випрямлячів. Збірник наукових праць Украӥнського державного університету залізничного транспорту. 2018. Вип. 178. C. 21-28. DOI: $\underline{10.18664 / 1994-}$ 7852.178.2018.138906.

5. Муха А. М. Електромагнітна сумісність 
перетворювачів підвищеної частоти електрорухомого складу 3 системи залізничної автоматики дільниць, електрифікованих постійним струмом. Електромагнітна сумісність та безпека на залізничному транспорті. 2013. № 6. С. 11-16.

6. Електричні системи i мережі: навч. посіб. / Ю. В. Малогулко, О. Б. Бурикін, Т. Л. Кацадзе, В. В. Нетребський; за ред. П. Д. Лежнюка. Вінниця: ВНТУ, 2020. Ч. 1. 200 с.

7. Scherbak Ya., Plakhtii O., Nerubatskyi V., Hordiienko D., Shelest D., Semenenko Yu. Analysis of exact and approximating dependences of the active resistance of conductor on the frequency of current under the action of skin effect. IEEE EUROCON 2021 - 19th International Conference on Smart Technologies. P. 438-442. DOI: $10.1109 /$ EUROCON52738.2021.9535581.

8. Губський П. В. Енергетичні канали живлення розподілених систем тягового електропостачання. Електрифікащія транспорту. 2018. № 15 . C. 23-30.

9. Нерубацький В. П., Плахтій О. А. Започаткування реалізації проєкту науково-технічної розробки наукових основ підвищення енергетичної ефективності та покращення якості електроенергії в електричних мережах. Збірка наукових праць IX наукової конференції «Наукові підсумки 2020 року» (Харків, 29 листопада 2020 р.). Харків: Технологічний Центр, 2020. С. 25.

10. Нерубацький В. П., Гордієнко Д. А. Підвищення енергоефективності системи тягового електропостачання електричного рухомого складу за допомогою інтегрованої системи SMART GRID: матеріали П'ятої Всеукраїнської науковопрактичної інтернет-конференції студентів, аспірантів і молодих вчених «Актуальні проблеми сучасної енергетики» (Херсон, 20-22 травня 2020 р.). Херсон: ПП «Резнік», 2020. С. 165-168.

11. Nerubatskyi V., Hordiienko D. Improving the energy efficiency of the traction power supply system of electric rolling stock with alternative energy sources. Proceedings of the V International Scientific and Practical Conference «Applied Scientific and Technical Research» (Ivano-Frankivsk, April 5-7, 2021). Ivano-Frankivsk: Vydavets' Kushnir H. M., 2021. Р. 344-346.

12. Нерубацький В. П., Плахтій О. А., Гордієнко Д. А., Шелест Д. А. Визначення дії скін-ефекту на додаткові втрати потужності від вищих гармонік в електричних мережах: тези доповідей Другої міжнародної науково-технічної конференції «Інтелектуальні транспортні технології» (Харків, 27-29 квітня 2021 р.). Харків: УкрДУЗТ, 2021. С. 139-141.

13. Энергоэффективный преобразовательный агрегат с функциями фильтрации гармоник выходного напряжения тяговой подстанции системы электроснабжения постоянного тока напряжением 3 кВ / В. М. Самсонкин, Н. В. Панасенко, В. В. Божко, Ю. П. Гончаров, А. В. Ересько, В. В. Замураев, Р. И. Любич, В. Г. Сыченко. Днепропетровск: Вестник ДНУжТ им. В. Лазаряна, 2008. Вып. 20. С. 66-72.

14. Щербак Я. В. Замкнутые системы компенсации неканонических гармоник полупроводниковых преобразователей. Харьков: Транспорт Украины, 1999. $256 \mathrm{c.}$

15. Сєдов С. О. Оброблення сигналів на базі операційних підсилювачів. Схемотехніка. Розрахунки: навч. посіб. Київ: КПІ ім. Ігоря Сікорського, 2017. 132 с.

16. Калабухов А. М., Петренко О. М., Чашка Ю. М. Електронні прилади та пристрої. Ч. 1. Електричні фільтри і напівпровідникові прилади: навч. посіб. Дніпропетровськ: РВВ ДНУ, 2008. 98 с.

17. Електроенергетика України. Структура, керування, інновації: монографія / І.В.Хоменко, О. А. Плахтій, В. П. Нерубацький, І. В. Стасюк. Харків: НТУ «ХПІ», ТОВ «Планета-Прінт», 2020. 132 c.

18. Анучин А. С. Системы управления электроприводов: учебн. для вузов. Киев: Издательский дом МЭИ, 2015. 373 с.

19. Крупський С. А., Гуда А. I. Ефективність мікроконтролерного управління двигуна постійного струму. Молодий вчений. 2019. № 1 (65). $\quad$ C. 270-272. DOI: $10.32839 / 2304-$ 5809/2019-1-65-62.

20. Щербак Я. В., Плахтий А. А., Нерубацкий В. П. Анализ энергетических характеристик активного четырёхквадрантного выпрямителя с различными типами широтно-импульсной модуляции. Вісник Національного технічного університету «Харківський політехнічний інститут». 2017. Вип. 27 (1249). С. 221-225.

21. Pivnyak G. G., Beshta O. O. A complex source of electrical energy for three-phase current based on a stand-alone voltage inverter. Naukovyi Visnyk Natsionalnoho Hirnychoho Universytetu. 2020. № 1. P. 89-93. DOI: 10.33271/nvngu/2020-1/089.

22. Семененко О. І., Супрун О. Д., Семененко Ю. О., Ткаченко М. П. Дослідження ефективності роботи згладжувальних пристроїв перетворювальних агрегатів тягових підстанцій постійного струму. Інформаційно-керуючі системи на залізничному транспорті. 2018 . № $6 . \quad$ C. 12-21. DOI: $10.18664 /$ ikszt.voi6.151636.

23. Нерубацький В. П., Плахтій О. А. Підвищення енергоефективності тягових підстанцій постійного струму шляхом застосування активних тягових випрямлячів 3 корекцією коефіцієнта потужності: матеріали 80 міжнародної науково-технічної 
конференції «Розвиток наукової та інноваційної діяльності на транспорті» (Харків, 24-26 квітня 2018 р.): збірник наукових праць Українського державного університету залізничного транспорту. Харків: УкрДУЗТ, 2018. Вип. 177. C. $79-81$.

24. Сиченко В. Г., Бадьор М. П., Зубенко В. А. Діагностування згладжуючих фільтрів тягових підстанцій постійного струму. Автоматика. Автоматизация. Электротехнические комплексы и системыл. 2000. № 2. С. 80-84.

25. Цымбал Л. Т., Черкасов А. Н., Панченко О. Ф. Аномальный скин-эффект в магнитном поле: зависимость от формы поверхности Ферми. Физика низких температур. 1998. Т. 24, № 12. C. $1157-1165$.

26. Гуцул О. В., Слободян В. 3. Дослідження частотної залежності скін-ефекту для провідників I-го та II-го роду. Zbiór artykułów naukowych. Konferencji Miedzynarodowej NaukowoPraktycznej "Inżynieria i technologia. Teoretyczne i praktyczne aspekty rozwoju współczesnej nauki" (30.03.201731.03.2017). Warszawa: Wydawca: Sp. z o.o. «Diamond trading tour», 2017. C. 42-46.

27. Карпов Ю. О., Ведміцький Ю. Г., Кухарчук В. В. Теоретичні основи електротехніки. Електромагнітне поле: підручник. Вінниця: ВНТУ, 2008. $407 \mathrm{c}$.

28. Кучерук I. M., Горбачук I. Т., Луцик П. П. Загальний курс фізики: у 3 т. Т. 2. Електрика i магнетизм. Вид. 2-ге, випр. Київ: Техніка, 2006. $452 \mathrm{c}$.

29. Муха А. М., Устименко Д. В. Досвід експлуатації контактної вставки полозу струмоприймача 3 матеріалу «Романіт-УВЛШ». Залізничний транспорт України. 2020. № 4. С. 15-21. DOI: 10.34029/2311-4061-2020-137-4-15-21.

30. Провода контактные из меди и её сплавов. Технические условия: ГОСТ 2584-86. [Действуют от 01.01.1988]. Москва, 1998. $11 \mathrm{c}$.

31. Ansys Maxwell 3D v.15 - Electromagnetic and Electromechanical Analysis: user's guide / Ansys Inc. Pittsburgh, 2012. 1006 p.

32. The design of electric machines using Maxwell \& Simplorer / Ansys Inc. Pittsburgh, 2013. 48 p.

Плахтий А. А., Нерубацкий В. П., Шелест Д. А., Цыбульник В. Р. Исследование влияния скинэффекта на потери мощности в системах тягового электроснабжения постоянного тока.

Аннотация. Приведены исследования гармонического состава тяговых токов в железнодорожной системе электроснабжения постоянного тока. В исследовании учтено влияние высших гармоник, обусловленных несимметрией питающего напряжения, гармоник трёхфазных выпрямителей тяговых подстанций, работу пассивного гибридного фильтра тяговой подстанции, а также влияние высших гармоник, предопределённых импульсным потреблением токов тяговым автономным инвертором напряжения электроподвижного состава с асинхронным тяговым электроприводом. На примере фильтра тяговой подстанции ЕЧ-20 регионального филиала «Южная железная дорога» АО «Укрзализныця» показано, что неканонические гармоники, обусловленные несимметрией питающего напряжения, не подавляются существующими режекторными звеньями фильтра. Влияние высших гармоник электроподвижного состава исследовано на примере работы асинхронного тягового электропривода с входным LC-фильтром и автономным инвертором напряжения электроподвижного состава. Исследование работы автономного инвертора напряжения электроподвижного состава выполнено для режимов синусоидальной широтно-импульсной модуляции и пространственно-векторной широтноимпульсной модуляции.

Показано, что применение пространственновекторной широтно-импульсной модуляции позволяет улучшить гармонический состав тяговых токов и снизить их коэффициент гармонических искажений. Определение гармонического состава и переходных процессов выполнено путём компьютерного моделирования в программе Matlab/Simulink. На основании определения гармонического состава в контактной сети приведены исследования влияния скин-эффекта на распределение плотности тока в сечении контактного провода системы железнодорожного электроснабжения постоянного тока. Данное исследование было выполнено также путём компьютерного моделирования в программе Ansys Maxwell. Как результат, скин-эффект вызывает увеличение эквивалентного активного сопротивления проводника, что приводит к увеличению дополнительных потерь мощности в контактном проводе систем железнодорожного электроснабжения, вызванных высшими гармониками тяговых подстанций и высшими гармониками электроподвижного состава.

Ключевые слова: скин-эффект, гармонический состав, система электроснабжения постоянного тока, потери мощности, тяговая подстанция постоянного тока.

Plakhtii O. A., Nerubatskyi V. P., Shelest D. A., Tsybulnyk V. R. Investigation of the influence of the skin effect on power losses in DC traction power supply systems.

Abstract. Investigations of the harmonic composition of traction currents in the railway DC power supply system 
are presented. The study takes into account the influence of higher harmonics due to asymmetry of supply voltage, harmonics of three-phase rectifiers of traction substations, operation of passive hybrid filter of traction substation, as well as the influence of higher harmonics due to pulse consumption of traction currents. On the example of the filter of the traction substation $\mathrm{ECH}-20$ of the regional branch "Southern Railway" of JSC "Ukrzaliznytsia" it is shown that non-canonical harmonics due to the asymmetry of the supply voltage are not suppressed by the existing notch links of the filter. The influence of higher harmonics of the electric rolling stock is performed on the example of operation of an asynchronous traction electric drive with an input LC-filter and an autonomous voltage inverter of the electric rolling stock. The study of the operation of the autonomous voltage inverter of electric rolling stock is performed for the modes of sinusoidal pulse-width modulation and spatial-vector pulse-width modulation.

It is shown that the application of spatial-vector pulsewidth modulation allows to improve the harmonic composition of traction currents and reduce their coefficient of harmonic distortions. Determination of harmonic composition and transients was performed by computer simulation in Matlab/Simulink. On the basis of the determined harmonic composition in the catenary, the study of the influence of the skin effect on the current density distribution in the cross section of the contact wire of the DC power supply system is presented. This study was also performed by computer simulation in Ansys Maxwell. As a result, the skin effect causes an increase in the equivalent active resistance of the conductor, which causes an increase in additional power losses in the contact wire of railway power supply systems caused by higher harmonics of traction substations and higher harmonics of electric rolling stock.

Key words: skin effect, harmonic composition, DC power supply system, power loss, DC traction substation.

Надійшла 14.10.2021 p

Плахтій Олександр Андрійович, к .m. н., доцент кафедри електроенергетики, електротехніки та електромеханіки, Украӥнський державний університет залізничного транспорту. E-mail: a.plakhtiy1989@gmail.com.

http://orcid.org/0000-0002-1535-8991.

Нерубацький Володимир Павлович, к. т. н., доцент, доцент кафедри електроенергетики, електротехніки та електромеханіки, Український державний університет залізничного транспорту. E-mail: NVP9@i.ua. ORCID: http://orcid.org/0000-0002-4309$601 X$.
Шелест Дмитро Андрійович, аспірант кафедри передачі електричної енергії, Національний технічний університет «Харківський політехнічний інститут». E-mail: $\quad$ shelllogist@gmail.com. ORCID: http://orcid.org/0000-0001-6095-658X.

Цибульник Владислав Романович, аспірант кафедри електроенергетики, електротехніки та електромеханіки, Украӥнський державний університет залізничного транспорту. E-mail: vladtsybulnyk@gmail.com.

ORCID: https://orcid.org/0000-0002-9895-6662.

Plakhtii Olexandr Andrievych, PhD, Associate Professor of Department of Electrical Energetics, Electrical Engineering and Electromechanics. Ukrainian State University of Railway Transport. E-mail: a.plakhtiy1989@gmail.com.

http://orcid.org/0000-0002-1535-8991.

Nerubatskyi Volodymyr Pavlovych, PhD, Associate Professor, Associate Professor of Department of Electrical Energetics, Electrical Engineering and Electromechanics. Ukrainian State University of Railway Transport. E-mail: NVP9@i.ua._ORCID: http://orcid.org/0000-0002-4309$\underline{601 X}$.

Shelest Dmytro Andrievych, postgraduate of Department of Electricity Transmission National Technical University «Kharkiv Polytechnic Institute». E-mail: shelllogist@gmail.com._ORCID: http://orcid.org/00000001-6095-658X.

Tsybulnyk Vladyslav Romanovych, postgraduate of Department of Electrical Energetics, Electrical Engineering and Electromechanics. Ukrainian State University of Railway Transport. E-mail: vladtsybulnyk@gmail.com. ORCID: 